\title{
Strategi pemasaran sapi potong di PT. Tunas Jaya Raya Abadi Nganjuk
}

\section{Beef cattle's marketing strategy in PT. Tunas Jaya Raya Abadi Nganjuk}

\author{
Jaisy Aghniarahim Putritamara*, Nanang Febrianto, dan Poespitasari Hazanah Ndaru \\ Fakultas Peternakan Universitas Brawijaya \\ J1 Veteran Malang (65145) Indonesia
}

Submitted: 18 September 2017, Accepted: 20 March 2018

\begin{abstract}
ABSTRAK: Penelitian dilakukan di PT. Tunas Jaya Raya Abadi Nganjuk. Tujuan penelitian untuk mengetahui kondisi lingkungan internal dan eksternal, menentukan strategi pemasaran berdasarkan kondisi lingkungan internal dan eksternal. Metode penelitian adalah metode survei dengan teknik pengumpulan data melalui observasi, wawancara dan dokumentasi. Analisis data menggunakan analisis SWOT. Hasil penelitian menunjukkan kondisi lingkungan yang ada di PT. Tunas Jaya Raya Abadi adalah cukup baik. Matriks faktor strategi internal yang menunjukkan nilai positif $(+)$, nilai kekuatan/strengths lebih besar daripada kelemahannya/weakness $(S=2,29>\mathrm{W}=0,71)$, sedangkan berdasarkan matriks faktor stategi eksternal menunjukkan nilai positif dengan nilai peluang/oppourtunity lebih besar daripada nilai ancaman/treaths $(\mathrm{O}=1,84>\mathrm{T}=0,70)$. Kesimpulan hasil penelitian adalah analisis lingkungan internal dan lingkungan eksternal pada PT. Tunas Jaya Raya Abadi menunjukkan hasil baik dan memberi prospek yang bagus untuk kemajuan usaha, dengan total skor faktor kekuatan dan peluang $(\mathrm{SO}=4,13)$. Penentuan strategi yang tepat adalah rapid strategy, yaitu strategi yang nilai faktor kekuatan lebih besar daripada peluang.
\end{abstract}

Kata kunci: Analisis SWOT, Sapi potong, Pemasaran,

ABSTRACT: This research conducted in PT. Tunas Jaya Raya Abadi Nganjuk. The objectives of this research were obtain a better understandin internal as well as exsternal environmental condition, secondly trying to covering the formulate the marketing strategi. Method that used in this research was a survey method, it contains observation, interview, and documentation. The data analyzed by SWOT analysis. The result showed internal strategy factors matrix give positive value where it strengths were stronger than it weakness $(S=2,29>\mathrm{W}=0,71)$. External strategy factors' matrix also give positive value where it opportunities values were bigger than it threats values $(O=1,84>T=0,70)$. From the result, we know that environmental condition in PT. Tunas Jaya Raya Abadi was very good, and gave good prospect for its progress in the future. It known from total score of strength and opportunities factors $(\mathrm{SO}=4.13)$. From SWOT analysis, strategy that will be taken was in the first quadrant where internal and external factors were positive. In general terms, it means that the environmental condition of PT. Tunas Jaya Raya Abadi, relatively has bigger opportunity than its weaknesses. The decision that made by PT. Tunas Jaya Raya Abadi for marketing strategy was rapid strategy by which all opportunity could be captured as marketing consideration.

Keywords: Beef cattle, Marketing, SWOT analysis

*Corresponding author: jaisyaghniatamara@ gmail.com 


\section{PENDAHULUAN}

Pembangunan peternakan merupakan bagian dari pembangunan sektor pertanian yang memiliki nilai strategis dalam memenuhi kebutuhan protein hewani asal ternak, kebutuhan tersebut semakin meningkat seiring dengan bertambahnya jumlah penduduk dan meningkatnya taraf hidup masyarakat. Proses pembangunan nasional berdampak pada perubahan konsumsi masyarakat yang awalnya mengkonsumsi karbohidrat kearah konsumsi protein hewani asal ternak seperti: daging, telur dan susu. Permintaan telur dan daging ayam dalam negeri saat ini dapat dipenuhi oleh produksi lokal, tetapi permintaan susu dan daging sapi pemenuhannya masih memerlukan pasokan dari luar negeri. Priyanto (2011) menyatakan kebutuhan daging sapi di Indonesia menunjukkan trend yang meningkat setiap tahun, tetapi import terus bertambah dengan laju yang semakin tinggi baik impor daging maupun impor sapi bakalan. Kondisi yang demikian menuntut para pemangku kepentingan (stakeholder) untuk segera menerapkan suatu strategi pengembangan peternakan sapi potong nasional untuk mengurangi ketergantungan pada impor.

Mukson, Roessali, dan Setiyawan (2014) menjelaskan bahwa peluang investasi usaha di bidang peternakan mempunyai potensi besar untuk dapat dikembangkan karena:

1) Pasar di dalam negeri untuk penduduk lebih dari 200 juta jiwa, merupakan potensi pasar yang sangat besar dan menjanjikan.

2) Adanya globalisasi perdagangan seperti WTO, AFTA dan APEC menjadi peluang pasar yang luar biasa besar asalkan pengusaha nasional dapat memanfaatkan. Sebaliknya jika tidak dapat memanfaatkannya maka Indonesia akan menjadi pasar bagi produk-produk peternakan dari negara lain.

3) Berkembangnya industri-industri yang membutuhkan bahan baku hasil-hasil peternakan seperti industri pengalengan dan pengolahan daging, sosis, industri pengolahan susu, mentega dari susu, industri pakan ternak dan lain-lain.

Bisnis peternakan sapi potong seperti juga bisnis yang lain mempunyai banyak persaingan. Persaingan terjadi tidak hanya di tingkat lokal, nasional dan regional tetapi terjadi pula di tingkat global. Salah satu kelemahan dalam bisnis sapi potong adalah sistem pemasaran dan perdagangan sapi potong di Indonesia belum effisien, sehingga peluang pasar yang ada belum dapat dimanfaatkan. Penyebab tidak efisiennya sistem pemasaran sapi dalam negeri adalah panjang dan kompleksnya jalur pemasaran sapi potong, sedangkan pada pola pemasaran daging asal impor jalur pemasaranya relatif lebih pendek dan dapat menekan biaya/margin pemasaran, sehingga memiliki kapasitas daya saing yang cukup tinggi. Berdasarkan uraian diatas, maka penelitian dilakukan untuk menetapkan strategi pemasaran yang tepat untuk pemasaran sapi potong di PT. Tunas Jaya Raya Abadi Nganjuk.

Tujuan dari penelitian adalah mengetahui kondisi lingkungan internal dan eksternal dari PT. Tunas Jaya Raya Abadi, menentukan strategi pemasaran berdasarkan kondisi lingkungan internal dan eksternal dari PT. Tunas Jaya Raya Abadi.

\section{MATERI DAN METODE}

Penelitian dilakukan di PT. Tunas Jaya Raya Abadi Desa Babadan, Kecamatan Pace, Kabupaten Nganjuk. Metode yang digunakan dalam penelitian adalah metode survei (Sugiyono, 2011). Teknik pengumpulan data melalui observasi, wawancara dan dokumentasi. Data penelitian terdiri dari data primer dan sekunder. Data primer merupakan data hasil penelitian yang diolah, sedangkan data sekunder merupakan data yang berasal dari Dinas Peternakan kabupaten, BPS dan literatur lain yang terkait dengan penelitian.

Data yang dianalisis terdiri dari data lingkungan internal meliputi faktor finansial, sumber daya manusia, pelayanan dan harga produk. Sedangkan data dari 
lingkungan eksternal meliputi lingkungan fisik, pesaing, konsumen, sosial budaya dan peran pemerintah. IFE (internal factor evaluation) dan EFE (external factor evaluation) digunakan untuk menganalisis fakor-faktor internal dan eksternal yang memengaruhi strategi pemasaran sapi potong. Setelah diketahui faktor internal dan eksternal kemudian dianalisis posisi strategis dari PT. Tunas Jaya Raya Abadi menggunakan matrik IE (internal external). Setelah diketahui posisi strategis maka dapat dirumuskan beberapa strategi alternatif menggunakan matriks SWOT (strengths weaknesses opportunities threats). Dari beberapa strategi alternatif kemudian dapat diambil satu prioritas strategi menggunakan matriks QSPM (quantitative strategy planning matrix).

Analisis SWOT merupakan identifikasi berbagai faktor secara stimulus untuk merumuskan strategi pemasaran pada perusahaan. Analisis ini didasarkan pada logika yang dapat memaksimalkan kekuatan dan peluang, namun secara bersamaan dapat meminimalkan kelemahan dan ancaman (Khusna, Daryanto, Utami, 2016). Rangkuti (2008) menambahkan proses pengambilan keputusan yang berkaitan dengan keputusan strategis selalu berkaitan dengan pengembangan bisnis, tujuan, strategi dan kebijakan perusahaan. Perencanaan strategis (strategi plannes) harus menganalisis faktor-faktor strategi perusahaan (kekuatan, kelemahan, peluang dan ancaman) dalam kondisi yang ada pada saat ini

\section{HASIL DAN PEMBAHASAN}

PT. Tunas Jaya Raya Abadi awal mula didirikannya adalah bergerak dalam bidang kopersi simpan pinjam. Pada awalnya koperasi simpan pinjam ini bernama KSP Perlindungan yang berkedudukan di Desa Sukomoro, Kecamatan Sukomoro, Kabupaten Nganjuk yang didirikan pada tahun 1970 dengan BH. No. 12/BH/II/12/70 tanggal 31 Maret 1970 dengan wilayah kerja meliputi kecamatan Sukomoro, kabupaten Nganjuk. Tahun 1997 KSP Perlindungan diubah namanya menjadi KSP Tunas Jaya dengan wilayah kerja meliputi seluruh exkarisidenan Kediri dengan SK No. 1209/PAD/KWK.13/IV/1997 tanggal 21 April 1997.

Tanggal 26 Januari 1999 diadakan Rapat Anggota Khusus bertempat dikantor KSP Tunas Jaya Tanjung Anom kabupaten Nganjuk. Rapat memutuskan menyetujui penggabungan $4 \mathrm{KSP}$ yaitu : KSP Tunas Jaya kabupaten Nganjuk, KSP Tunas Karyakarisidenan Madiun, KSP Tunas Perkasakarisidenan Surabaya dan KSP Tunas Mekar karisidenan Malang. Pada tanggal 9 Februari 1999, bergabung menjadi KSP Tunas Artha Mandiri dengan wilayah kerja meliputi seluruh wilayah Jawa Timur sesuai perubahan BH. No. 09/BH/KWK.13/III/99 tanggal 11 Maret 1999 dan berkedudukan di jalan Bromo I. No. 1 Nganjuk dan terhitung mulai bulan Februari 2003 ditetapkan kantor pusat KSP Tunas Artha Mandiriberkedudukan di jalan Dermojoyo No. 34 Nganjuk.

PT Tunas Jaya Raya Abadi mempunyai 5 unit usaha yang bernaung dibawahnya, tetapi dalam hal manajemen dan pengelolaanya sudah berjalan sendirisendiri. Lima unit usaha tersebut meliputi perkebunan, peternakan, pertanian, SPBU dan Shorum motor. Kelima unit usaha tersebut sekarang ini mampu berjalan seiringan dan bekerja sama untuk pengembangan usaha.

Salah satu unit usaha dalam PT Tunas Jaya Raya Abadi adalah bidang peternakan yakni penggemukan sapi potong. Awal mula usaha yang dijalankan bukan penggemukan sapi potong, melainkan usaha peternakan sapi perah. Tetapi lama-kelamaan usaha sapi perah tersebut mengalami penurunan produksi dan populasi, hal ini dikarenakan Kabupaten Nganjuk mempunyai cuaca sangat panas sehingga tidak cocok untuk pengembangan peternakan sapi perah. Berawal dari kondisi tersebut, kemudian pemilik beralih ke usaha penggemukan sapi potong karena banyak sekali sapi bakalan yang bagus yang berasal dari daerah Nganjuk dan sekitarnya. 


\section{Perumusan strategi pemasaran}

Analisis SWOT merupakan identifikasi berbagai faktor secara stimulus untuk merumuskan strategi pemasaran pada perusahaan. Analisis didasarkan pada logika yang dapat memaksimalkan kekuatan dan peluang, namun secara bersamaan dapat meminimalkan kelemahan dan ancaman. Proses pengambilan keputusan yang berkaitan dengan keputusan strategis selalu berkaitan dengan pengembangan bisnis, tujuan, strategi dan kebijakan perusahaan. Perencanaan strategis harus menganalisis faktor-faktor strategi perusahaan (kekuatan, kelemahan, peluang dan ancaman) dalam kondisi yang ada saat ini (Kusuma, Raharja dan Saleh, 2013). Analisis didasarkan asumsi bahwa suatu strategi yang efektif akan memaksimalkan kekuatan dan peluang, meminimalkan kelemahan dan ancaman.

Matriks internal factor evaluation (IFE) dan Matriks ekternal factor evaluation (EFE) digunakan untuk mengevaluasi fakto-faktor internal lingkungan (kekuatan dan kelemahan) dan eksternal lingkungan (peluang dan ancaman). Skor yang di dapatkan dari analisis matriks ini menunjukkan kemam-puan perusahaan dalam memanfaatkan kekuatan dan mengatasi kelemahan yang ada, menunjukkan kemampuan dalam memperoleh peluang dan mengatasi ancaman dari eksternal.

Hasil analisis lingkungan internal dan eksternal, di peroleh hasil penjumlahan skor total pada matriks IFE dan EFE masing-masing sebesar 3,00 dan 2,54 (hasil analisis IFE dan EFE dapat dilihat pada tabel 1 dan 2). Angka pada matriks IFE menunjukkan bahwa kekuatan atau keunggulan yang dimiliki PT Tunas Jaya Raya Abadi melebihi kelemahan yang ada, sehingga kondisi tersebut merupakan satu keuntungan yang harus dimanfaatkan dan dimaksimalkan sebaik mungkin. Sedangkan angka yang terdapat pada matriks EFE mengindikasikan bahwa kondisi yang ada pada saat ini cukup memberi dukungan dan kesempatan bagi PT Tunas Jaya Raya Abadi untuk mengembangkan usahanya, dengan memanfaatkan peluang yang ada semaksimal mungkin serta meminimalkan ancaman yang timbul. 
Tabel 1. Hasil evaluasi faktor internal (IFE)

\begin{tabular}{|c|c|c|c|}
\hline Kekuatan & Bobot & Rating & Skor \\
\hline $\begin{array}{l}\text { Kondisi keuangan yang cukup baik, berjalan lancar dan memberi } \\
\text { ruang gerak yang cukup untuk pengembangan usaha }\end{array}$ & 0,18 & 4 & 0,72 \\
\hline Servis atau pelayanan kepada konsumen yang cukup baik & 0,08 & 3 & 0,24 \\
\hline $\begin{array}{l}\text { Lokasi perusahaan yang strategis yaitu berada ditepi jalan raya, dekat } \\
\text { dengan kota, ketersediaan tenaga kerja dan bahan pakan yang me- } \\
\text { madai }\end{array}$ & 0,16 & 4 & 0,64 \\
\hline Kesejahteraan karyawan diperhatikan & 0,15 & 2 & 0,30 \\
\hline Mempunyai jaringan pemasaran yang tetap dan kontinyu (luas) & 0,05 & 3 & 0,15 \\
\hline Pengalaman berusaha yang lebih dari 10 tahun & 0.12 & 2 & 0,24 \\
\hline Sub Total & & & 2,29 \\
\hline \multicolumn{4}{|l|}{ Kelemahan } \\
\hline Fasilitas-fasilitas produksi yang kurang lengkap & 0,05 & 2 & 0,10 \\
\hline Unsur promosi kurang maksimal & 0,10 & 3 & 0,30 \\
\hline Rendahnya kualitas sumberdaya manusia yang dimiliki & 0,15 & 1 & 0,15 \\
\hline Kurangnya tenaga marketing & 0,08 & 2 & 0,16 \\
\hline Sub Total & & & 0,71 \\
\hline Total & & & 3,00 \\
\hline
\end{tabular}

Tabel 2. Hasil evaluasi faktor eksternal (EFE)

\begin{tabular}{lccc}
\multicolumn{1}{c}{ Peluang } & Bobot & Rating & Skor \\
\hline $\begin{array}{l}\text { Meningkatnya permintaan dan daya beli masyarakat terhadap daging } \\
\text { sapi seiring membaiknya kondisi perekonomian }\end{array}$ & 0,12 & 4 & 0,48 \\
Tidak ada ancaman pendatang atau pesaing baru & 0,18 & 3 & 0,54 \\
$\begin{array}{l}\text { Hubungan dan kerja sama dengan para supplier dan konsumen yang } \\
\text { berjalan baik, terpercaya dan harmonis }\end{array}$ & 0,15 & 2 & 0,30 \\
Wilayah pemasaran produk masih cukup luas & 0,12 & 3 & 0,36 \\
Harga jual yang terjangkau & 0,08 & 2 & 0,16 \\
\hline \multicolumn{1}{c}{ Sub Total } & & & 1,84 \\
\hline
\end{tabular}

\begin{tabular}{llll}
\hline \multicolumn{2}{c}{ Ancaman } & & \\
\hline Kenaikan BBM (Bahan Bakar Minyak), tarif listrik dan telfon & 0,10 & 2 & 0,20 \\
Selera konsumen yang berubah-ubah & 0,10 & 2 & 0,20 \\
Adanya fluktuasi harga sapi bakalan & 0,15 & 2 & 0,30 \\
\hline \multicolumn{1}{c}{ Sub Total } & & & 0,70 \\
\hline \multicolumn{1}{c}{ Total } & & 2,54 \\
\hline
\end{tabular}

Hasil kombinasi skor total dari matriks IFE dan EFE menunjukkan faktor internal dan eksternal bernilai positif, artinya bahwa lingkungan yang dihadapi secara relatif berpeluang lebih besar dibanding ancaman, kekuatannya relatif lebih unggul dibanding dengan kelemahannya. Arah kebijakan yang tepat 
dilaksanakan untuk kondisi ini adalah growth strategy atau strategi pertumbuhan. Hasil penelitian sejalan dengan Adinata, Sari, dan Rahayu (2012) bahwa alternatif strategi utama yang dapat diterapkan dalam mengembangkan usaha ternak sapi potong yaitu mengoptimalkan dan mengembangkan kemampuan internal peternak, memanfaatkan sumber daya alam yang tersedia untuk meningkatkan skala usaha ternak sapi potong menjadi lebih maju, pengenalan mengenai teknologi pengolahan pakan berbasis limbah pertanian dan bibit ternak sapi unggul yang disesuaikan dengan kondisi wilayah setempat, menjalin usaha kemitraan bersama pemerintah dan pihak ketiga.

\section{Matriks internal eksternal (IE)}

Hasil dari penjumlahan faktor strategis internal dan eksternal yang dipadukan dalam matriks Internal Eksternal (IE) menunjukkan posisi perusahaan ada pada sel 5. Kondisi pada sel 5, strategi yang diterapkan adalah stability and growth strategy. Siregar (2012) menjelaskan Stability and growth strategy yaitu tanpa merubah strategi yang telah ada dan berusaha mencapai pertumbuhan baik dalam penjualan dan profit. Tekanan strategi lebih pada perluasan pasar untuk meningkatkan penjualan dan keuntungan. Kondisi seperti ini, yang perlu dilakukan diantaranya pengembangan produk, pasar dan promosi. Tujuannya agar perusahaan dapat menggunakan kekuatan yang dimiliki untuk mengatasi ancaman. Matriks Internal-Eksternal (IE) PT Tunas Jaya Raya Abadi dapat dilihat pada Tabel 3.

Tabel 3 Matriks Internal-Eksternal (IE) PT Tunas Jaya Raya Abadi

\begin{tabular}{ccccc}
\hline & & \multicolumn{3}{c}{ Total Nilai IFE yang di bobot } \\
& & Kuat & Rata-rata & Lemah \\
& & $3,0-4,0$ & $2,0-2,99$ & $1,0-1,99$ \\
\hline \multirow{3}{*}{$\begin{array}{c}\text { Total Nilai EFE yang } \\
\text { di bobot }\end{array}$} & Sedang $2,0-2,99$ & IV & II & III \\
& Rendah 2,0-1,99 & VII & VIII & IX \\
\hline
\end{tabular}

\section{Matriks SWOT}

Matriks SWOT dapat disusun 4 strategi utama yaitu strategi SO, WO, ST dan WT. Masing-masing memiliki karakteristik tersendiri sehingga dalam implementasi strategi dilaksanakan secara bersama-sama dan saling mendukung satu dengan lainnya.

Strategi SO dibuat berdasarkan jalan pikiran perusahaan, yaitu dengan memanfaatkan seluruh kekuatan untuk merebut dan memanfaatkan peluang sebesar-besarnya. Strategi ST dengan menggunakan kekuatan yang dimiliki perusahaan untuk mengatasi ancaman.
Strategi WO ditetapkan berdasarkan pemanfaatan peluang yang ada dengan cara meminimalkan kelemahan yang ada, sedangkan strategi WT didasarkan pada kegiatan yang bersifat defensif artinya berusaha meminimalkan kelemahan yang ada serta menghindari ancaman.

Berdasarkan rumusan variabelvariabel kekuatan (strengths), kelemahan (weaknesesses), peluang (opportunities) dan ancaman (treaths) diatas, maka dapat dibuat matriks SWOT PT Tunas Jaya Raya Abadi serta dapat disusun 4 strategi utama SO, WO, ST dan WT (tabel 4). 
Tabel 4. Matrik SWOT PT Tunas Jaya Raya Abadi

\begin{tabular}{|c|c|c|}
\hline & Strengths $(\mathbf{S})$ & Weaknesses (W) \\
\hline EFE & $\begin{array}{l}\text { 1. Kondisi keuangan yang cukup } \\
\text { baik, berjalan lancar dan memberi } \\
\text { ruang gerak yang cukup untuk } \\
\text { pengembangan usaha } \\
\text { 2. Servis atau pelayanan kepada } \\
\text { konsumen yang cukup baik } \\
\text { 3. Lokasi perusahaan yang strategis } \\
\text { yaitu berada ditepi jalan raya, } \\
\text { dekat dengan kota, ketersediaan } \\
\text { tenaga kerja dan bahan pakan yang } \\
\text { memadai } \\
\text { 4. Kesejahteraan } \\
\text { diperhatikan } \\
\text { 5. Mempunyai jaringan pemasaran } \\
\text { yang tetap dan kontinue (luas) } \\
\text { 6. Pengalaman berusaha yang lebih } \\
\text { dari } 10 \text { tahun }\end{array}$ & $\begin{array}{l}\text { 1. Fasilitas-fasilitas produksi } \\
\text { yang kurang lengkap } \\
\text { 2. Unsur promosi kurang } \\
\text { maksimal } \\
\text { 3. Rendahnya kualitas } \\
\begin{array}{l}\text { sumberdaya manusia yang } \\
\text { dimiliki }\end{array} \\
\text { 4. Kurangnya tenaga marketing }\end{array}$ \\
\hline Opportunities (O) & Strategi SO & Strategi WO \\
\hline 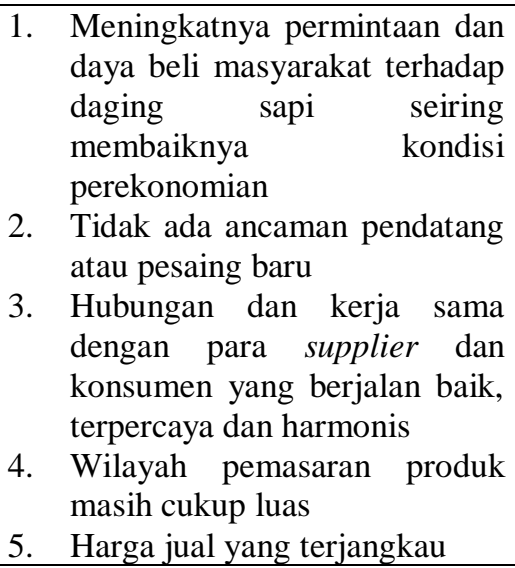 & $\begin{array}{l}\text { 1. Meningkatkan pelayanan terhadap } \\
\text { konsumen } \\
\text { 2. Membina dan menjaga hubungan } \\
\text { baik dengan konsumen } \\
\text { 3. Memanfaatkan nama baik PT } \\
\text { Tunas Jaya Raya Abadi dan } \\
\text { meningkatkan kepercayaan } \\
\text { terhadap konsumen } \\
\text { 4. Memanfaatkan modal untuk } \\
\text { memperluas daerah pemasaran }\end{array}$ & 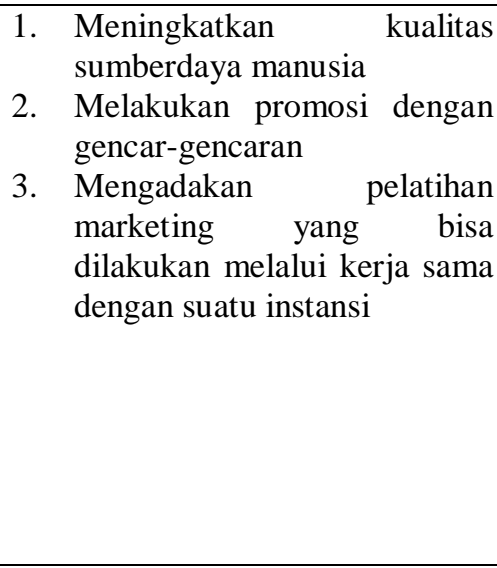 \\
\hline Threats $(\mathbf{T})$ & Strategi ST & Strategi WT \\
\hline $\begin{array}{l}\text { 1. } \begin{array}{l}\text { Kenaikan BBM (Bahan Bakar } \\
\text { Minyak), tarif listrik dan telfon }\end{array} \\
\text { 2. } \begin{array}{l}\text { Selera konsumen yang } \\
\text { berubah-ubah }\end{array} \\
\text { 3. } \begin{array}{l}\text { Adanya fluktuasi harga sapi } \\
\text { bakalan }\end{array}\end{array}$ & $\begin{array}{ll}\text { 1. } & \text { Meningkatkan kualitas produk } \\
\text { 2. } & \text { Memperketat biaya pemasaran } \\
\text { 3. } & \text { Menjaga ketersediaan sapi bakalan } \\
& \text { untuk mengantisipasi kelangkaan }\end{array}$ & $\begin{array}{l}\text { Melakukan diversifikasi } \\
\text { usaha } \\
\text { 2. Penambahan fasilitas-fasilitas } \\
\text { produksi }\end{array}$ \\
\hline
\end{tabular}

Hasil analisis diperoleh kondisi lingkungan yang ada di PT Tunas Jaya Raya Abadi adalah cukup baik, hal ini berdasarkan pada matriks faktor strategi internal yang menunjukkan nilai positif (+), nilai kekuatan/strengths lebih besar daripada kelemahannya/weakness $(\mathrm{S}=$ $2,29>\mathrm{W}=0,71)$. Matriks faktor stategi eksternal menunjukkan nilai positif dimana nilai peluang/oppourtunity lebih besar daripada nilai ancaman/treaths $(\mathrm{O}=1,84>$ $\mathrm{T}=0,70)$. Kondisi lingkungan internal dan eksternal yang positif maka arah kebijakan yang tepat dilaksanakan pada kondisi ini adalah Growth Strategy. Lebih lanjut
Nazarudin, Suryahadi dan Sarma (2011) mengungkapkan growth strategi dibagi lagi menjadi dua yakni selective strategy dan rapid stategy untuk lebih memfokuskan strategi yang akan di laksanakan. Selective strategy merupakan stategi yang nilai faktor kekuatan/strengths lebih kecil daripada peluang/opportunity. Strategi ini tidak semua peluang bisa ditangkap sehingga dalam pengembangan usaha harus diprioritaskan mana yang terlebih dahulu dan pada akhirnya bisa lebih fokus sedangkan rapid stategy adalah strategi yang nilai faktor kekuatan/strengths lebih besar daripada 
peluang/oppourtunity. Karena faktor kekuatan yang lebih unggul, pada rapid stategysemua peluang bisa ditangkap oleh perusahaan.

Nilai faktor kekuatan/strengths lebih besar dari pada peluang/opportunity maka PT Tunas Jaya Raya Abadi dapat menerapkan rapid stategy yaitu dengan menangkap semua peluang yang dimiliki, seperti:

1. Meningkatnya permintaan dan daya beli masyarakat terhadap daging sapi seiring membaiknya kondisi perekonomian maka dapat dimanfaatkan dengan pemberian servis atau pelayanan kepada konsumen yang baik.

2. Tidak adanya ancaman pendatang atau pesaing baru dan wilayah pemasaran produk masih cukup luas hal ini dapat ditindaklanjuti dengan adanya pembukaan cabang baru mengingat kondisi keungan yang cukup baik mampu memberi ruang gerak untuk pengembangan usaha.

3. Harga jual yang terjangkau oleh konsumen dapat mendatangkan profit yang maksimal sehingga berdampak juga pada kesejahteraan karyawan juga meningkat.

4. Hubungan dan kerja sama dengan para supplier dan konsumen yang berjalan baik dan harmonis dapat dimanfaatkan untuk memperluas jaringan pemasaran dan memperbanyak konsumen.

Hal ini di pertegas dengan temuan Ramadhan, Nindyantoro, dan Suyitman (2014) bahwa Strategi ST (StrenghtThreat) pengembangan usaha ternak sapi potong yang dihasilkan adalah: meningkatkan sumber daya manusia dengan meningkatkan pengetahuan peternak, menjalin kerjasama dengan berbagai pihak untuk meningkatkan produktivitas serta menjaga kepercayaan konsumen dengan kualitas produk lokal melalui manajemen produksi yang baik.

\section{KESIMPULAN}

Analisis lingkungan internal dan lingkungan eksternal yang dilakukan di PT Tunas Jaya Raya Abadi menunjukkan hasil yang baik dan memberi prospek yang ba- gus untuk kemajuan usaha tersebut dimasa mendatang. Berdasarkan total skor faktor kekuatan dan peluang $(\mathrm{SO}=4,13)$. Hasil analisis SWOT strategi yang diambil berada pada posisi pada kuadran I yang berarti faktor internal dan eksternal bernilai positif, hal ini berarti bahwa lingkungan yang dihadapi secara relatif berpeluang lebih besar dibanding ancaman, kekuatannya relatif lebih unggul dibanding dengan kelemahannya. Penentuan strategi yang tepat dengan menerapkan rapid stategy yaitu strategi yang nilai faktor kekuatan/strengths lebih besar daripada peluang/oppourtunity. Selain itu juga menerapkan stategi SO yaitu dengan meningkatkan pelayanan terhadap konsumen, membina dan menjaga hubungan baik dengan konsumen dan memanfaatkan modal untuk memperluas daerah pemasaran.

\section{SARAN}

Beberapa saran yang dapat di rekomendasikan adalah PT. Tunas Jaya Raya Abadi untuk terus melakukan pengembangan dan peningkatan terhadap kualitas sapi hasil penggemukan, memperluas daerah pemasaran, mengevaluasi kegiatan pemasarannya dan mempertahankan hubungan baik dengan konsumen dan pemasok sapi bakalan.

\section{DAFTAR PUSTAKA}

Adinata, K.I., Sari A.I, dan Rahayu E.T. 2012. Strategi Pengembangan Usaha Sapi Potong di Kecamatan Mojolaban Kabupaten Sukoharjo. Tropical Animal Husbandry, 1(1), $24-32$.

Khusna, A., Daryanto H.K., Utami M.M.D., 2016. Pengembangan Strategi Agribisnis Sapi Potong di Kabupaten Bondowoso. Jurnal Ilmu Pertanian Indonesia, 21(2), $69-75$.

Kusuma, T., Raharja S., dan Saleh A. 2013. Strategi Pemasaran Sapi potong di CV Septia Anugrah Jakarta. Jurnal Manajemen IKM, 8(1), $71-78$. 
Mukson W., Roessali dan Setiyawan H. 2014. Analisis Wilayah Pengembangan Sapi Potong dalam Mendukung Swasembada Daging di Jawa Tengah. Jurnal Peternakan Indonesia, 16(1), 26 - 32.

Nazarudin, R., Suryahadi dan Sarma M. 2011. Analisis Strategi Pemasaran Peternakan Ayam CV Intan Jaya Abadi Sukabumi. Jurnal Manajemen IKM, 6(2), 125-132.

Priyanto, D. 2011. Strategi Pengembangan Usaha Ternak Sapi Potong Dalam Mendukung Program Swasembada Daging Sapi Dan Kerbau Tahun 2014. Jurnal Penelitian dan Pengembangan Pertanian, 30(3), $108-116$.
Ramadhan, D.R., Nindyantoro, dan Suyitman. 2014. Status Keberlanjutan Wilayah Peternakan Sapi Potong untuk Pengembangan Kawasan Agropolitan di Kabupaten Bondowoso. Jurnal Peternakan Indonesia, 16(2), $78-88$.

Rangkuti, F. 2008. Analisis SWOT, Teknik Membedah Kasus Bisnis. Jakarta : Gramedia Pustaka Utama.

Siregar, G. 2012. Analisis Kelayakan dan Strategi Pengembangan Usaha Ternak Sapi Potong. Jurnal Agrium, 17(3), $192-201$.

Sugiyono. 2011. Statitistika untuk Penelitian. Bandung: Alfabeta. 